\title{
The Influence of Social Media Marketing Instagram, Word of Mouth and Brand Awareness of Purchase Decisions on Arthenis Tour and Travel
}

\author{
Novita Alfian ${ }^{1}$, Sengguruh Nilowardono ${ }^{2}$ \\ Narotama University Surabaya, Indonesia \\ novitaalfia@gmail.com
}

\begin{abstract}
Abstract : The purpose of this study is to analyze the extent of Social Media Marketing Instagram, Word of Mouth, and Brand Awareness of purchasing decisions at Arthenis Tour and Travel. This study uses primary data obtained from customer answers. The instrument uses a questionnaire with a Likert scale. The population in this study are 105 Arthenis Tour and Travel consumers and taking a sample of 83 people. The hypothesis is used with multiple linear regression tests. Based on the results of the study, obtained the value of $\mathrm{F}_{\text {count }}(198,348)>\mathrm{F}_{\text {table }}(2,72)$ related to simultaneous and partial on Social Media Marketing Instargram, Word of Mouth and Brand Awareness of the expected variables as a result of purchase. It is expected for travel agents can support their Instagram, using Word of Mouth and Brand Awareness so they can increase their sales.
\end{abstract}

Keywords: Social Media Marketing Instagram, Word Of Mouth, Brand Awareness and Purchasing Decisions.

\section{INTRODUCTION}

\section{Research Background and Motives}

The use of social media is growing especially in Indonesia affect consumers in communicating with your fellow consumers even online stores. Based on the Optima Web marketing, social media marketing efforts by creating the visibility, presence and the presence of the website in the online social media networks. One of the popular social media use in social media marketing is Instagram.

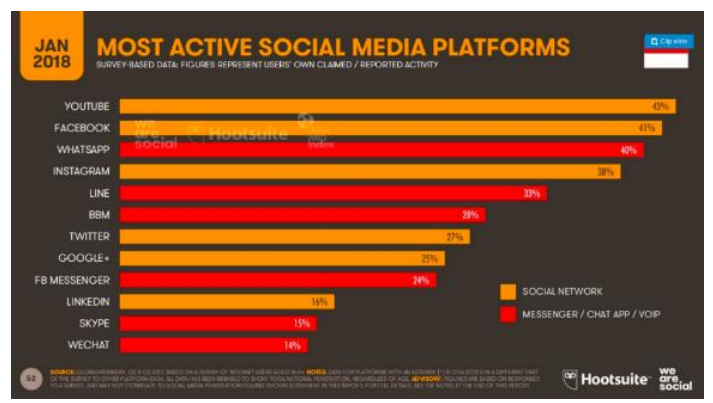

Fig. 1. Percentage of the most active social media accessible in Indonesia 2018

The Influence of Social Media Marketing Instagram, Word of Mouth and Brand Awareness of Purchase Decisions on Arthenis Tour and Travel

Novita Alfian, Sengguruh Nilowardono 
Instagram is a photo-sharing application that is being liked by everyone. The advantage of Instagram as a marketing tool is that Instagram can deliver a message from a brand through photos, images or videos. As a new Travel Service, Arthenis Tour and Travel needs to improve communication in its marketing. One form of marketing communication that utilizes social networking as a way to communicate a product or service is e-WOM (Electronic Word of Mouth). Word of Mouth Communication or communication from mouth to mouth is a communication process in the form of giving recommendations both individually and in groups to a product or service that aims to provide information personally (Kotler \& Keller, 2009)Kotler \& Keller, (2009). The occurrence of word of mouth triggers new potential customers to make purchases in a product that they have heard from other people. When prospective customers already know about the products that have been offered through promotion or also.

Besides word of mouth the use of social media should be used as a channel to enhance and build brand awareness with the aim of becoming top of mind, according to (D. Durianto, Darmadi, Sugiarto, \& Sitinjak, 2001)Darmadi Durianto (2001) Brand Awareness is the ability of a prospective buyer to recognize, recall a brand as part of a specific product category.

Based on this background, the problem to be examined are:

1. Are Instagram Social Media Marketing, Word of Mouth, and Brand Awareness by simultaneous significant influence on purchasing decisions in Arthenis Tour and Travel?

2. Are Instagram Social Media Marketing, Word of Mouth and Brand Awareness influential on the purchasing decisions at Arthenis Tour and Travel?

3. Which variables of Instagram Social Media Marketing, Word of Mouth, and Brand Awareness have the dominant influence on purchasing decisions at Arthenis Tour and Travel?

The purpose of this study is to analyze the extent of the influence of Instagram Social Media Marketing, Word of Mouth, and Brand Awareness on purchasing decisions at Arthenis Tour and Travel?

\section{LITERATURE REVIEW}

\section{Social Media Marketing}

Social media marketing is a form of marketing that uses social media to market a product, service, brand or issue by utilizing tools on social media such as blogs, facebook, twitter, Instagram, and other media sharing sites. Whereas opinions according to (Purnomo, 2017)Wahyu Dian (2017) Social media is a form of promotion through digital media. Social media is used to build engagement with consumers. Also, social media has unique features that enable conversations to form word of mouth. "Social media marketing is often used, is Instagram. Many brands use Instagram to improve their visual marketing strategies that focus on using images and videos.

\section{Word of Mouth}

According to (Kotler \& Keller, 2012)Kotler \& Keller (2012) Word of Mouth Communication (WOM) or mouth communication is a communication process in the form of giving recommendations both individually and in groups to a product or service that aims to provide personal information.

Word of mouth is a form of promotion. Promotion is an activity that conveys the benefits of a product and persuades customers to buy it (Kotler \& Armstrong, 2008)Kotler \& Armstrong (2008). Basically promotion is a communication effort. Marketing communication is a marketing activity that seeks to disseminate information, influence and remind products or services of a company. Word of mouth can shape consumer confidence. Therefore the level of movement of such information is very fast. If word of mouth is positive, it will create profits for the company, but if word of mouth is negative, it will cause public distrust for the product or service.

The Influence of Social Media Marketing Instagram, Word of Mouth and Brand Awareness of Purchase Decisions on Arthenis Tour and Travel

Novita Alfian, Sengguruh Nilowardono 


\section{Brand Awareness}

According to (Handayani \& et al, 2010)Handayani, et al (2010), defines brand awareness is the ability of consumers to recognize or remember that a brand belongs to a particular product category. Whereas according to (Darmadi Durianto, Sugiarto, \& Sitinjak, 2004)Durianto, et al (2004), brand awareness is the ability of a prospective buyer to recognize, recall a brand as part of a particular product category.

Consumers will likely buy the brand they already knew, because they feel safe with something that was familiar. Brand awareness is the ability of consumers to recognize or recall that a brand is part of a specific product category. Brand awareness requires a range of continuum, ranging from the uncertain feeling that particular brand had previously been known to end up being the belief that the brand is the only brand in a given product category. (Aaker, 1991)Aaker,(2014).

\section{Purchasing Decisions}

In making purchasing decisions on a product basically is closely related to consumer behavior. Consumer behavior is an important element in marketing activities of a product that needs to be known by the company, because the company basically does not know about what is in the mind of a consumer at the time before, while, and after purchasing the product.

Purchasing decisions are a condition of the purchase process of buyers who actually buy the product. Where consumers get approval, find information about a particular product or brand and improve each alternative can solve problems that arise related to purchasing decisions (Kotler, 2008)Kotler (2008).

\section{RESEARCH METHOD}

\section{Research Structure}

Based on the aims and relevant literature, this study proposes a research model of the effects of Social Media Marketing, Word of Mouth and Brand Awareness, and the model is showed in Figure 2:

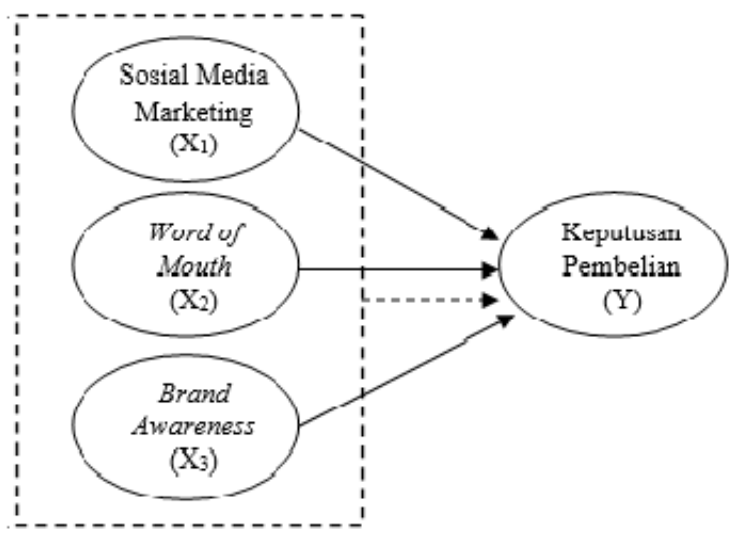

Fig. 2. Research Framework

\section{Research Hypotheses}

H1: Social Media Marketing, Word of Mouth Instagram, and Brand Awareness simultaneously of significant effect against the purchasing decision on a Arthenis Tour and Travel.

The Influence of Social Media Marketing Instagram, Word of Mouth and Brand Awareness of Purchase Decisions on Arthenis Tour and Travel

Novita Alfian, Sengguruh Nilowardono 
H2: Instagram Social Media Marketing, Word of Mouth, and Brand Awareness had a partial effect on purchasing decisions at Arthenis Tour and Travel.

H3: Which of Instagram's Social Media Marketing, Word of Mouth, and Brand Awareness have dominant influence on purchasing decisions at Arthenis Tour and Travel.

\section{The type of research}

The type of research used in this research is the correlational quantitative method of descriptive research approach and verbal analysis.

\section{Population and Sampling}

The population in this research are consumers using Arthenis Tour and Travel services for periods Mar 2018 up to Octobuntuker 2018 as much as 105 customer with a sample of 83 customer.

\section{Types, Sources and Data Collection Techniques}

The variables in this study used were the first independent variable (X1) is Social Media Marketing, the second independent variable (X2) is Word of Mouth, the third independent variable (X3) is Brand Awareness and the dependent variable used in this study is purchasing decision.

\section{Data Analysis Techniques}

1. Validity and Reliability Test

2. Classical Assumption Test

3. Multiple Linear Regression Test

$$
\mathbf{Y}=\mathbf{a}+\mathbf{b} 1 \mathrm{X} 1+\mathrm{b} 2 \mathrm{X} 2+\mathrm{b} 3 \mathrm{X} 3+\mathrm{e}
$$

Dimana:

$\mathrm{Y} \quad=$ purchasing decision

a $\quad=$ konstanta

$\mathrm{b} 1, \mathrm{~b} 2, \mathrm{~b} 3=$ koefeisien regresi dari variabel $\mathrm{X} 1, \mathrm{X} 2, \mathrm{X} 3$

$\mathrm{X} 1=$ social media marketing instagram

$\mathrm{X} 2=$ word of mouth

$\mathrm{X} 3=$ brand awareness

e $\quad=$ error, variabel interference

4. Hypothesis Test

a. Partial Test (T Test)

This test aims to test whether the independent variables (social media marketing, word of mouth, and brand awareness) on the dependent variable (purchase decision) have a partial or separate effect

b. F Test

The Influence of Social Media Marketing Instagram, Word of Mouth and Brand Awareness of Purchase Decisions on Arthenis Tour and Travel

Novita Alfian, Sengguruh Nilowardono 
The F test was used to determine the effect of the Arthenis Tour and Travel Purchase Decision process based on Instagram social media marketing, word of mouth, and brand awareness), and Word of Mouth as a simultaneous process of purchasing decisions.

\section{RESULTS AND DISCUSSION}

\section{Demografi Customer}

Table 1. Characteristics Customers

\begin{tabular}{|c|c|c|}
\hline Jenis Kelamin & Jumlah & Persen $(\%)$ \\
\hline Laki-laki & 35 & 42,2 \\
\hline Perempuan & 48 & 57,8 \\
\hline Jumlah & 100 & 100 \\
\hline usia & Jumlah & Persen $(\%)$ \\
\hline$<20$ tahun & 4 & 4,8 \\
\hline $21-30$ tahun & 46 & 55,4 \\
\hline $31-40$ tahun & 20 & 24,1 \\
\hline $41-50$ tahun & 10 & 12 \\
\hline$>50$ tahun & 3 & 3,6 \\
\hline Jumlah & 100 & 100 \\
\hline Pekerjaan & Jumlah & Persen $(\%)$ \\
\hline Pelajar / mahasiswa & 30 & 36,1 \\
\hline Pegawai / karyawan & 35 & 42,2 \\
\hline wiraswasta & 18 & 21,7 \\
\hline Jumlah & 100 & 100 \\
\hline
\end{tabular}

\section{Test Validity and Reliability}

Based on the validity of all statement items has a correlation value that is greater than $r$ table (greater than 0.213), so that all items submitted questions are declared valid and feasible to be analyzed. Based on the reliability of all variable values, both the independent variable and the dependent variable all meet the requirements, meaning that all items are declared reliable or reliable

\section{Multiple Analysis Test Results}

Table 2. Results of Multiple Regression Analysis Test

\begin{tabular}{lccc} 
Variabel & Koefisien Regresi & Thitung $_{\text {hig. }}$ & Sig. \\
\hline Konstanta & 0,325 & 2,140 & 0,035 \\
\hline
\end{tabular}

The Influence of Social Media Marketing Instagram, Word of Mouth and Brand Awareness of Purchase 


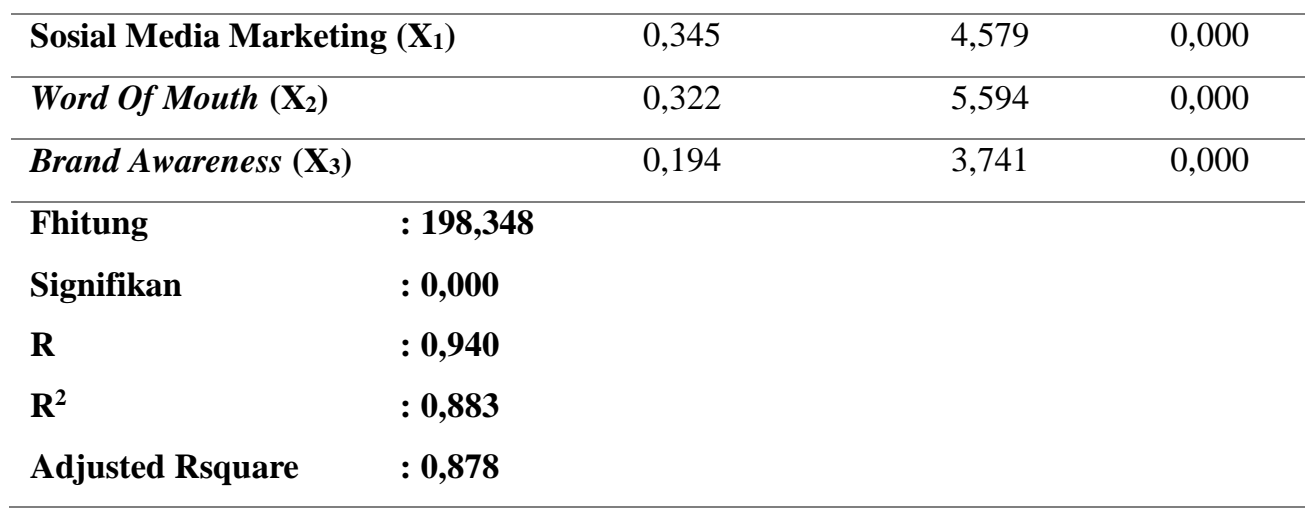

By entering the values obtained from the SPSS calculations above, multiple regression equations can be obtained, that is:

$$
\begin{aligned}
& \hat{Y}=a+b_{x 1}+b_{x 2}+b_{x 3} \\
& \hat{Y}=0,325+0,345_{x 1}+0,322_{x 2}+0,194_{x 3}
\end{aligned}
$$

Description :

1. Constants of 0.325 , this indicates the value of the purchase decision (Y) of 0.325 if the independent variable Social Media Marketing (X1), Word Of Mouth (X2) and Brand Awareness (X3) are considered to be constant.

2. Regression coefficient $\mathrm{X} 1$ is $\mathrm{bl}=0.345$, meaning that if the Social Media Marketing variable (X1) is increased and other variables Word of Mouth (X2) and Brand Awareness (X3) remain, then the purchase decision is predicted to increase by 0.345 units.

3. The regression coefficient X2 is b2 $=0.322$, meaning that if the Word of Mouth variable (X2) is increased and other variables are Social Media Marketing (X1) and Brand Awareness (X3) remain, then the purchasing decision is predicted to increase by 0.322 units.

4. $\mathrm{X} 3$ regression coefficient is $\mathrm{b} 3=0.194$, meaning that if the Brand Awareness (X3) variable is increased and other variables Social Media Marketing (X1) and Word Of Mouth (X2) remain, then the purchase decision is predicted to increase by 0.194 units.

In addition to the coefficient of determination also in the regression calculation the value obtained is 0.940 . The correlation coefficient of 0.940 is a very strong category. Based on the biggest value, it can be seen from the largest beta value, namely on the Social Media Marketing (X1) variable of 0.345. With this, it can be concluded that the Social Media Marketing variable (X1) has the most dominant influence on purchasing decisions (Y).

\section{T Test}

Based on the partial influence in getting each value of the $t$ test as follows:), tcount $X 1(4,579)>t$ table (2.35), then Ho is rejected or in other words Social Media Marketing (X1) has an effect on the dependent variable namely purchasing decision (Y), $\mathrm{t}$ count $\mathrm{X} 2(5,594)>\mathrm{t}$ table $(2.35)$, then Ho is rejected or in other words Word of Mouth (X2) has an effect on the dependent variable namely purchasing decision (Y), $t$ count $\mathrm{X} 3(3,741)>t$ table $(2,35)$, then Ho is rejected or in other words Brand Awareness (X3) has an effect on the dependent variable, that is purchasing decision (Y).

\section{F Test}

The Influence of Social Media Marketing Instagram, Word of Mouth and Brand Awareness of Purchase Decisions on Arthenis Tour and Travel

Novita Alfian, Sengguruh Nilowardono 
Obtained a value of fhitung (198.348) $\mathrm{f}_{\text {tabel }}>(2.72)$, then Hi accepted. It means that there is a simultaneous influence of Social Media Marketing (X 1), Word Of Mouth and Brand Awareness (X 3) against the variable i.e. purchasing decisions (Y). Adjusted R 0.883, meaning variables tied to purchasing decisions (y) can be explained by the variable free Social Media Marketing (X 1), Word Of Mouth (X 2) and Brand Awareness (X 3) of 0.883 or $88.3 \%$ and the rest $(100 \% 88.3 \%=-11.7 \%)$ is explained by the variable others are not included in the model (the error factor). Based on the dominant variables can be known from the largest beta values in variables of Social Media Marketing (X 1) of 0.345. This can be summed up with the Social Media Marketing variables (X 1) has the most dominant influence towards purchasing decisions (Y).

\section{DISCUSSION}

Social media marketing is a form of marketing that uses social media to market a product, service, brand or issue by utilizing tools on social media such as blogs, facebook, twitter, Instagram, and other media sharing sites. Whereas opinions according to (Purnomo, 2017)Wahyu Dian (2017) Social media is a form of promotion through digital media. Social media is used to build engagement with consumers. Also, social media has unique features that enable conversations to form word of mouth.

One popular social media used in social media marketing is Instagram. Instagram is a photosharing application that is loved by everyone. The advantage of Instagram as a marketing tool is that Instagram can deliver messages from a brand through photos, pictures or videos. Instagram is no longer present as a selfie-platform or just a social media media, but has become a new alternative in launching marketing action in the business world. Only by creating Instagram social media accounts, businesses and sellers can easily be connected to many potential buyers. So that it can be said that promotional media that are considered effective and current are promotions through social media accounts such as Instagram. Summarized by Kompas Tekno from We Are Social, a British media company that works with Hootsuite, the average Indonesian spends three hours 23 minutes a day accessing social media.

The impact of social media is very real on increasing website traffic and increasing online sales. Social media has been used as one of the tools used to market products or commonly referred to as social media marketing. Social media marketing is a process that encourages individuals to promote through Instagram and to communicate by utilizing a much larger community that is more likely to do marketing than through traditional advertising channels.

The tourism industry is an industry that includes a variety of roles. Along with the development of the age of the tourism industry is growing rapidly marked by the proliferation of companies engaged in the field of travel agents which led to very tight competition, followed by the advancement of knowledge and technology that is very rapid which affects the level of purchasing power and customer satisfaction. As Arthenis Tour and Travel is a travel agency that focuses on selling domestic tour packages at low prices that only rely on sales through social media. As a new Travel Service, Arthenis Tour and Travel needs to improve communication in its marketing. One form of marketing communication that utilizes social networking as a way of communicating a product or service is e-WOM (Electronic Word of Mouth). Word of Mouth Communication or communication from mouth to mouth is a communication process in the form of giving recommendations both individually and in groups to a product or service that aims to provide information personally (Kotler \& Keller, 2009)Kotler \& Keller, (2009).

Word of mouth is also important because it is communication that produces good conversation. Someone will ask other people about the quality of an item or service before they decide to buy it. Therefore word of mouth can influence someone's buying decision in making a purchase (Sernovitz, 2009)Sernovitz, (2009).

The Influence of Social Media Marketing Instagram, Word of Mouth and Brand Awareness of Purchase 
The occurrence of word of mouth triggers new customers to make purchases in a product or service that they have heard from other people. When prospective customers already know about services that have been offered through promotion or get information from mouth to mouth, then prospective customers have the right to consider before they decide on a decision in purchasing services. When consumers have used a product, consumers will evaluate services that have been used, if the service provides satisfaction and a positive impression on consumers, then positive word of mouth is likely to occur, and vice versa. Word of mouth can also mean that the consequences of satisfaction and impression of consumers on a product that has been consumed. Word of mouth will be positive if consumers have felt satisfied and give a positive impression of the product that has been used and will be negative when consumers are not satisfied and have a negative impression on the product they use.

(Handayani \& et al, 2010)Handayani, et al (2010), defining brand awareness is the ability of potential consumers to recognize or remember that a brand belongs to a particular product category. Whereas according to (Darmadi Durianto et al., 2004)Durianto, et al (2004), brand awareness is the ability of a prospective buyer to recognize, recall a brand as part of a particular product category.

Consumers will tend to buy brands that they already know, because they feel safe with something they already know. Brand awareness is the ability of consumers to recognize or recall that a brand is part of a particular product category. Brand awareness requires a continuum of reach, that is, starting from the uncertain feeling that a certain brand has been known to the point that it becomes a belief that the brand is the only brand in a product category. (Aaker, 2014)Aaker, (2014).

\section{CONCLUSION AND SUGGESTIONS}

\section{Conclusions}

1. Social Media Marketing Instagram, Word of Mouth, and Brand Awareness simultaneously have a significant effect on purchasing decisions at Arthenis Tour and Travel

2. Instagram Social Media Marketing, Word of Mouth, and Brand Awareness partially affected the purchasing decisions at Arthenis Tour and Travel

3. Based on the dominant variable, it can be seen from the largest beta value, namely on the Social Media Marketing (X1) variable of 0.345 . With this, it can be concluded that the Social Media Marketing variable (X1) has the most dominant influence on purchasing decisions (Y)

\section{Advice}

Based on the analysis of the research that has been stated in advance, the following suggestions can be taken:

1. The results of this study are expected to be a reference or input for the development of management science and add to the study of management science about social media marketing especially through Instagram Social Media Marketing, Word of Mouth, and Brand Awareness on the level of purchasing decisions.

2. The results of this study are expected to be an input for Arthenis Tour and Travel to use or manage their Instagram social media channels. It can also be a guide or recommendation for travel managers in managing Instagram social media, utilizing Word of Mouth and Brand Awareness so that later managers can run their business better. As well as for other parties this research is also expected to be able to assist in the presentation of information to conduct similar research.

The Influence of Social Media Marketing Instagram, Word of Mouth and Brand Awareness of Purchase Decisions on Arthenis Tour and Travel

Novita Alfian, Sengguruh Nilowardono 


\section{REFERENCES}

Aaker, D. (1991). Managing Brand Equity: Capitalizing on the Value of a Brand Name. New York: The Free Press.

Aaker, D. (2014). Building Strong Brands. Jakarta: Bumi Aksara.

Durianto, D., Darmadi, Sugiarto, \& Sitinjak, T. (2001). Strategi Menaklukan Pasar melalui Riset Ekuitas dan Perilaku Merek. Jakarta: PT. Gramedia Pustaka Utama. https://doi.org/10.1126/science.213.4504.214

Durianto, D., Sugiarto, \& Sitinjak, T. (2004). Strategi Menaklukkan PasarMelalui Riset Ekuitas dan Perilaku Merek. Jakarta: PT. Gramedia Pustaka Utama.

Handayani, D., \& et al. (2010). The Official MIM Academy Coursebook Brand Operation. Jakarta: Esensi.

Kotler, P. (2008). Manajemen Pemasaran (12th ed.). Jakarta: PT Indeks.

Kotler, P., \& Armstrong, G. (2008). Prinsip-Prinsip Pemasaran (12th ed.). Jakarta: Erlangga.

Kotler, P., \& Keller, K. L. (2009). Manajemen Pemasaran (13th ed.). Jakarta: Erlangga.

Kotler, P., \& Keller, K. L. (2012). Manajemen Pemasaran (12th ed.). Jakarta: Erlangga.

Purnomo, W. D. (2017). Apa itu social media marketing?

Sernovitz. (2009). Word of Mouth Marketing. Jakarta: PT. Gramedia Pustaka Utama.

The Influence of Social Media Marketing Instagram, Word of Mouth and Brand Awareness of Purchase Decisions on Arthenis Tour and Travel

Novita Alfian, Sengguruh Nilowardono 